\title{
Effect of Liquid Biofertilizers and Inorganic Fertilizers on Yield and Quality Attributes of Broccoli (Brassica oleracea L. var. italica)
}

\author{
M. V. Pawde, A. M. Bhosale and S. J. Syed* \\ Department of Horticulture, College of Agriculture, VNMKV Parbhani (M. S.), India \\ *Corresponding author
}

\begin{tabular}{|l|}
\hline K e y w o r d s \\
$\begin{array}{l}\text { Broccoli, } \\
\text { Biofertilizers, } \\
\text { Chemical fertilizers, } \\
\text { Azotobacter, PSB, } \\
\text { Azotophos }\end{array}$ \\
\hline Article Info \\
\hline $\begin{array}{l}\text { Accepted: } \\
\text { 04 September } 2019 \\
\text { Available Online: } \\
\text { 10 October } 2019\end{array}$ \\
\hline
\end{tabular}

A B S T R A C T
The investigation was carried out at the Department of Horticulture, College of Agriculture, VNMKV, Parbhani (M. S.) during Rabi 2018-19 to study the effect of liquid biofertilizers and inorganic fertilizers on growth attributes of broccoli (Brassica oleracea L. var. italica) Cv. Green magic. Two factors were taken for study, the first factor was the chemical fertilizers at three levels $(125 \%, 100 \%$ and $75 \%$ of RDF) and the second factor was the different biofertilizers (Azotobacter, PSB and Azotophos). The experimental design adopted was factorial randomized block design with 12 treatment combinations. The characters viz., chlorophyll contents $(0.34 \mathrm{mg} / 100 \mathrm{~g})$, ascorbic acid $(125.04 \mathrm{mg} / 100 \mathrm{~g})$, total yield per plant $(1268.80 \mathrm{~g})$, total yield per plot $(31.72 \mathrm{gkg})$ and total yield per hectare (469.97 q) of broccoli were recorded highest with the application of $125 \%$ $\mathrm{RDF}+$ Azotophos. The treatment of $125 \% \mathrm{RDF}+$ Azotophos was significant than other treatments.

\section{Introduction}

Broccoli (Brassica oleraceaL. var.italica) belongs to the family Brassicaceae. It has thick clusters of flower buds that form edible heads. These heads are green, purple and white in color. Broccoli is highly nutritious and has been considered as anti-cancerous food by the American Cancer Society because it contains Indole-3-carbinol which helps to fight breast and lung cancer. It also contains flavonoids, phenolic acids and soluble dietary fiber, diasaccharides, beta carotene and amino acids (including a high content of lysine) too and it has antioxidant and anticancer activity (Podsędek, 2007). It is a good source of vitamin $A$, calcium and vitamin $B_{2}$ and it is also rich source of most minerals especially of potassium, phosphorus, sulphur and magnesium and micro elements (Aboul Nasr and Ragab, 2000; Sander, 1996). China is the top world producer of broccoli (FAO, 2009). In recent years cultivation of broccoli has gained momentum in India and has become 
increasingly popular with Indian growers for last couple of years. In the recent past, broccoli cultivation has been taken up successfully by some farmers around Nasik, Pune and Thane. Recently it is proved that broccoli can grow successfully under Marathwada region.

Application of liquid bio-fertilizers inoculation in vegetable crops has been of much significance as Azotobacter and Azospirillium for atmospheric nitrogen, also known for synthesis of biologically growth promoting substances whereas, PSB are important microbes in releasing and making available phosphorus by colonizing the root surface of growing plant root. They also improve the plant growth due to increase in nutrient uptake particularly phosphorus, zinc and other micro-nutrients, production of growth promoting substances and resistance to plant pathogen. These bio-fertilizers are organic in origin and thus, are absolutely safe. Therefore, it is essential to adopt a strategy of integrated nutrient management using combination of chemical fertilizers, organic manures and biofertilizers, so as to minimize the cost of production and to maintain biological productivity of soil, particularly because the farmers are reluctant to adopt recommended fertilizer doses due to the high cost and risk of crop failures on account of aberrant weather conditions. Hence, keeping all the points in view, the present study was undertaken to study the effect of liquid biofertilizers and inorganic fertilizer doses on yield and quality of broccoli (Brassica oleracea L.var. italica) at the department of horticulture, VNMKV Parbhani.

\section{Materials and Methods}

The experiment was conducted at Department of Horticulture, College of Agriculture, VNMKV, Parbhani that comes under subtropical region and is geographically situated between $19^{\circ} 16^{\prime} \mathrm{N}$ latitude and $76^{\circ}$ $47^{\prime} \mathrm{E}$ longitude. The experiment consisted of twelve treatment combinations with three levels of inorganic $\left(125 \%\right.$ RDF $\left(\mathrm{F}_{1}\right)$ 150:100:75 kg/ha, $100 \quad \% \quad \mathrm{RDF} \quad\left(\mathrm{F}_{2}\right) \quad-$ 120:80:60 kg/ha and $75 \% \mathrm{RDF}\left(\mathrm{F}_{3}\right)$ 90:60:45 $\mathrm{kg} / \mathrm{ha}$ ) and four level of biofertilizers (without biofertilizers $\left(\mathrm{B}_{0}\right)$, Azotophos $\left(\mathrm{B}_{1}\right)$, PSB $\left(\mathrm{B}_{2}\right)$ and Azotophos $\left(\mathrm{B}_{3}\right)$. The Factorial randomized block design was adopted with three replications. The experimental field was thoroughly ploughed to a depth of $30 \mathrm{~cm}$ and harrowed twice. The field was laid out at a plot size of $3 \times 2.25 \mathrm{~m}$. The biofertilizers (Azotobacter, PSB and Azotophos) were applied by drenching after transplanting of the seedlings. They were transplanted in ridges and furrow system at a spacing of $60 \times 45 \mathrm{~cm}$. Standard cultural and management practices were adopted. Observations were recorded on yield and quality traits i. e. chlorophyll contents, ascorbic acid, total yield per plant, total yield per plot and total yield per hectare of broccoli. Least significant difference at 5\% level was used for finding the significant differences among the treatment means. The data obtained from selected plants were subjected to analysis of variance Panse and Sukhatme (1961).

\section{Results and Discussion}

\section{Quality parameters}

\section{Chlorophyll}

Chlorophyll was found maximum with the combined application of biofertilizers and inorganic fertilizers. It is clear from the result that the maximum chlorophyll content was $(0.22 \mathrm{mg} / 100 \mathrm{~g})$ recorded under $100 \% \mathrm{RDF}$ $\left(\mathrm{F}_{2}\right)$, followed by $125 \% \mathrm{RDF}\left(\mathrm{F}_{1}\right)$. Among biofertilizers maximum chlorophyll contents $(0.31 \mathrm{mg} / 100 \mathrm{~g})$ was recorded in plants which were applied with Azotophos $\left(\mathrm{B}_{3}\right)$. The interaction treatment of $125 \% \mathrm{RDF}+$ 
Azotophos $\left(\mathrm{F}_{1} \mathrm{~B}_{3}\right)$ had significantly increased chlorophyll contents $(0.34 \mathrm{mg} / 100 \mathrm{~g})$, followed by $100 \% \mathrm{RDF}+$ Azotophos $\left(\mathrm{F}_{2} \mathrm{~B}_{3}\right)$.The increase in availability of nitrogen and phosphorus might have resulted in greater content of chlorophyll in broccoli leaves. Similar results were obtained by Chaudhary et al., (2017).

\section{Ascorbic acid}

The maximum ascorbic acid content (107.14 $\mathrm{mg} / 100 \mathrm{~g}$ ) was found under level of $100 \%$ $\operatorname{RDF}\left(\mathrm{F}_{2}\right)$, followed by $125 \% \operatorname{RDF}\left(\mathrm{F}_{1}\right)$ and $75 \%$ RDF $\left(\mathrm{F}_{3}\right)$. Among the biofertilizers levels the maximum ascorbic acid contents $(119.61 \mathrm{mg} / 100 \mathrm{~g})$ was recorded under Azotophos $\left(\mathrm{B}_{3}\right)$ followed by PSB $\left(\mathrm{B}_{2}\right)$ and Azotobacter $\left(\mathrm{B}_{1}\right)$. The interaction of chemical fertilizers and biofertilizers i.e. $125 \% \mathrm{RDF}+$ Azotophos $\left(\mathrm{F}_{1} \mathrm{~B}_{3}\right)$ recorded highest ascorbic acid contents $(125.04 \mathrm{mg} / 100 \mathrm{~g})$ followed by $100 \% \mathrm{RDF}+$ Azotophos $\left(\mathrm{F}_{2} \mathrm{~B}_{3}\right)$.The respective increase in ascorbic acid contents might be due to the increased efficiency of microbial inoculants to fix atmospheric nitrogen, increase in availability of phosphorous and secretion of growth promoting substances which accelerates the physiological process like carbohydrates synthesis etc. Similar results were obtained by Chaudhary et al., (2017), Shivran et al.,(2017)and Singh et al., (2018).

\section{Yield parameters}

The highest yield per plant (980.90 g) was recorded in $100 \% \mathrm{RDF}\left(\mathrm{F}_{2}\right)$ followed by 125 $\% \operatorname{RDF}\left(\mathrm{F}_{1}\right)$ and $75 \% \operatorname{RDF}\left(\mathrm{F}_{3}\right)$. Among biofertilizers maximum yield per plant (1198 g) was recorded under Azotophos $\left(\mathrm{B}_{3}\right)$ followed by PSB $\left(\mathrm{B}_{2}\right)$ and Azotobacter $\left(\mathrm{B}_{1}\right)$. The interaction treatment of $125 \% \mathrm{RDF}+$ Azotophos $\left(\mathrm{F}_{1} \mathrm{~B}_{3}\right)$ showed significant increase in yield per plant (1268 $\mathrm{g}$ ) which is followed by $100 \% \mathrm{RDF}+$ Azotophos $\left(\mathrm{F}_{2} \mathrm{~B}_{3}\right)$.
This might be due to better root proliferation, more photosynthesis efficiency, and enhanced food accumulation, increased availability of atmospheric nitrogen and soil phosphorus by microbial inoculants and synthesis of plant hormones at all the stages of growth and development by the combined application of biofertilizers and inorganic fertilizers. Similar results were obtained by Thakur et al., (2015) and Panchalet al., (2018).

The highest yield per plot $(24.67 \mathrm{~kg})$ and yield per hectare (371.08 q) were recorded in $100 \%$ RDF $\left(\mathrm{F}_{2}\right)$ which was followed by $125 \% \mathrm{RDF}$ $\left(\mathrm{F}_{1}\right)$ and $75 \% \operatorname{RDF}\left(\mathrm{F}_{3}\right)$. The biofertilizers Azotophos $\left(\mathrm{B}_{3}\right)$ level recorded the maximum yield per plot $(29.84 \mathrm{~kg})$ and yield per hectare $(443.68 \mathrm{q})$, followed by PSB $\left(\mathrm{B}_{2}\right)$ and Azotobacter $\left(\mathrm{B}_{1}\right)$.

The maximum yield per plot $(31.72 \mathrm{~kg})$ and yield per hectare $(469.67 \mathrm{q})$ were recorded in $125 \% \mathrm{RDF}+$ Azotophos $\left(\mathrm{F}_{1} \mathrm{~B}_{3}\right)$, followed by $100 \% \mathrm{RDF}+$ Azotophos $\left(\mathrm{F}_{2} \mathrm{~B}_{3}\right)$. The increase in yield might be due to the nitrogen fixer's phosphorus solubilizers, greater availability of nutrients in the soil and better nodulation under the influence of inoculation resulted in better growth and development. Similar results were obtained by Ramana et al., (2011), Meenaet al., (2017) and Chaudhary et al., (2017).

Interaction of chemical fertilizer and biofertilizers enhanced the vegetative and reproductive growth. Therefore, amongst all the treatments, interaction of $125 \% \mathrm{RDF}$ and Azotophos can be considered as most beneficial in terms of growth. From the present investigation it is revealed that, soil application of chemical fertilizers and biofertilizers is an instant and effective way of application which give significant yield and quality parameters of plant and physicochemical properties of curd of broccoli (Table 1 and 2). 
Table.1 Effect of chemical fertilizers and biofertilizers on quality parameters of broccoli

\begin{tabular}{|c|c|c|}
\hline \multirow{2}{*}{$\begin{array}{c}\text { Treatment } \\
\text { Factor: - A } \\
\text { Chemical Fertilizers }\end{array}$} & \multicolumn{2}{|c|}{ Quality Parameters } \\
\hline & Chlorophyll (mg/100g) & Ascorbic acid (mg/100g) \\
\hline $\mathbf{F}_{1}$ & 0.21 & 106.91 \\
\hline $\mathbf{F}_{2}$ & 0.22 & 107.14 \\
\hline $\mathbf{F}_{3}$ & 0.19 & 103.37 \\
\hline $\mathrm{SE}_{ \pm}$ & 0.01 & 0.98 \\
\hline CD at 5\% level & 0.03 & 2.86 \\
\hline \multicolumn{3}{|l|}{$\begin{array}{c}\text { Factor :- B } \\
\text { Biofertilizers }\end{array}$} \\
\hline $\mathbf{B}_{0}$ & 0.16 & 94.43 \\
\hline $\mathbf{B}_{1}$ & 0.17 & 100.97 \\
\hline $\mathbf{B}_{2}$ & 0.21 & 108.21 \\
\hline $\mathbf{B}_{3}$ & 0.31 & 119.61 \\
\hline $\mathrm{SE}_{ \pm}$ & 0.01 & 1.13 \\
\hline CD at 5\% level & 0.03 & 3.31 \\
\hline \multicolumn{3}{|l|}{ Interactions (FXB) } \\
\hline $\mathbf{F}_{1} \mathbf{B}_{0}$ & 0.16 & 95.02 \\
\hline $\mathbf{F}_{1} \mathbf{B}_{1}$ & 0.17 & 98.57 \\
\hline $\mathbf{F}_{1} \mathbf{B}_{2}$ & 0.22 & 109.03 \\
\hline$F_{1} B_{3}$ & 0.34 & 125.04 \\
\hline $\mathbf{F}_{2} \mathbf{B}_{0}$ & 0.16 & 94.44 \\
\hline $\mathbf{F}_{2} \mathbf{B}_{1}$ & 0.18 & 103.28 \\
\hline $\mathbf{F}_{2} \mathbf{B}_{2}$ & 0.23 & 110.75 \\
\hline $\mathbf{F}_{2} \mathbf{B}_{3}$ & 0.31 & 120.07 \\
\hline $\mathbf{F}_{\mathbf{3}} \mathbf{B}_{\mathbf{0}}$ & 0.14 & 93.83 \\
\hline $\mathbf{F}_{3} \mathbf{B}_{1}$ & 0.17 & 101.07 \\
\hline $\mathbf{F}_{3} \mathbf{B}_{2}$ & 0.18 & 104.85 \\
\hline $\mathbf{F}_{3} \mathbf{B}_{3}$ & 0.28 & 113.72 \\
\hline $\mathrm{SE} \pm$ & 0.01 & 1.95 \\
\hline CD at 5\% level & $\mathbf{0 . 0 3}$ & 5.73 \\
\hline
\end{tabular}


Table.2 Effect of chemical fertilizers and biofertilizers on yield parameters of broccoli

\begin{tabular}{|c|c|c|c|}
\hline Treatment & 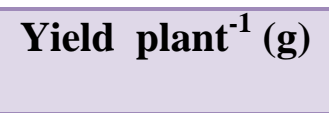 & $\begin{array}{c}\text { Yield per plot } \\
{ }_{\mathbf{1}}(\mathbf{k g})\end{array}$ & $\begin{array}{c}\text { Yield per hectare } \\
\mathbf{1}_{(\mathbf{q})}\end{array}$ \\
\hline \multicolumn{4}{|c|}{$\begin{array}{c}\text { Factor :- A } \\
\text { Chemical Fertilizers }\end{array}$} \\
\hline$F_{1}$ & 980.60 & 24.52 & 362.61 \\
\hline $\mathbf{F}_{2}$ & 986.90 & 24.67 & 371.08 \\
\hline $\mathbf{F}_{3}$ & 903.10 & 22.50 & 334.51 \\
\hline $\mathrm{SE}_{ \pm}$ & 14.72 & 0.43 & 5.75 \\
\hline CD at 5\% level & 43.17 & 1.26 & 16.85 \\
\hline \multicolumn{4}{|l|}{$\begin{array}{c}\text { Factor :- B } \\
\text { Biofertilizers }\end{array}$} \\
\hline $\mathbf{B}_{0}$ & 699.47 & 17.49 & 265.74 \\
\hline $\mathbf{B}_{1}$ & 908.93 & 22.72 & 336.65 \\
\hline $\mathbf{B}_{2}$ & 1021.07 & 25.53 & 378.20 \\
\hline $\mathbf{B}_{3}$ & 1198.00 & 29.84 & 443.68 \\
\hline $\mathrm{SE}_{ \pm}$ & 16.99 & 0.50 & 6.64 \\
\hline CD at $5 \%$ level & 49.85 & 1.46 & 19.46 \\
\hline \multicolumn{4}{|l|}{ Interactions (FXB) } \\
\hline$F_{1} B_{0}$ & 729.20 & 18.23 & 267.85 \\
\hline$F_{1} B_{1}$ & 848.00 & 21.20 & 314.01 \\
\hline $\mathbf{F}_{1} \mathbf{B}_{2}$ & 1076.40 & 26.91 & 398.61 \\
\hline $\mathbf{F}_{1} \mathbf{B}_{3}$ & 1268.80 & 31.72 & 469.97 \\
\hline$F_{2} B_{0}$ & 764.40 & 19.11 & 305.38 \\
\hline $\mathbf{F}_{2} \mathbf{B}_{1}$ & 968.00 & 24.20 & 358.51 \\
\hline $\mathbf{F}_{2} \mathbf{B}_{2}$ & 1023.20 & 25.58 & 379.05 \\
\hline $\mathbf{F}_{2} \mathbf{B}_{3}$ & 1192.00 & 29.80 & 441.37 \\
\hline $\mathbf{F}_{3} \mathbf{B}_{0}$ & 604.80 & 15.12 & 223.99 \\
\hline $\mathbf{F}_{3} \mathbf{B}_{1}$ & 910.80 & 22.77 & 337.43 \\
\hline$F_{3} B_{2}$ & 963.60 & 24.09 & 356.93 \\
\hline $\mathbf{F}_{3} \mathbf{B}_{3}$ & 1133.20 & 28.00 & 419.70 \\
\hline $\mathrm{SE}_{ \pm}$ & 29.44 & 0.86 & 11.49 \\
\hline CD at $5 \%$ level & 86.34 & 2.52 & 33.71 \\
\hline
\end{tabular}




\section{References}

Aboul, N. H. and Ragab, W. S. M. (2000).Yield, head quality and nutritional composition of a new late flowering broccoli variety grown under Assiut conditions. Assiut J. of Agricultural Science, 31(1): 55-77.

Chaudhary, M., Jat, R.K., Chand, P. and Chaudhary, R. (2017).Effect of biofertilizers on growth, yield, and quality of knolkhol (Brassica caulorapa.L). $J$. of Pharmacognosy andPhytochemistry, 6 (6): 2234-2237.

Chaudhary, S., Paliwal, R. (2017).Effect of Bio-organics and mineral nutrients on yield,quality and economics of sprouting broccoli (Brassica oleracea var.italica).International $J$. of Current Microbiology and Applied Sciences, 6 (12): 742749.

FAO statistics, (2009). Production year book.Food and Agriculture Organization, Rome, Italy.

Meena, K., Ram, R.B., Meena, M.L., Meena, J.K. and Meena, D.C. (2017). Effect of Organic Manures and Bio-Fertilizers on Growth, Yield and Quality of Broccoli (Brassica oleracea var. italic P lenck.) Cv. KTS-1, Chemical Science Review and Letter,6(24), 2153-2158.

Panchal, B.H. Patel, V.K. Patel, K.P. and Khimani, R.A. (2018) Effect of biofertilizers, organic manures and chemical fertilizers on microbial population, yield and attributes and quality of sweet corn (Zea mays L., saccharata) cv. Madhuri. International $J$. of Current Microbiology and Applied science, 7 (9): 2423-2431.

Podsedek, A. (2007). Natural antioxidants and antioxidant capacity of Brassica veget ables.LWT 40:1-11

Ramana, V., Ramakrishna, M., Purushotham, K. and Reddy, B.K. (2011). Effect of bio-fertilizers on growth, yield and quality of French bean (Phaseolus vulgaris L.).Vegetable Science, 38 (1):35-38.

Shivran.B.C., Meena ML., Ola AL., Chaudhary. G R, Meena, J. K, Atal.MK, (2017). Impact of biofertilizers and zinc on biochemical parameters of sprouting broccoli (Brassica oleracea. Var. italica) under Lukhnow conditions. J. of Pharmacognosy and Phytochemistry, 6 (6); 2065-2067.

Singh, B., Singh, K.,Talwar, D., Jindal, S.K and Sardana.V.S. (2018). Influence of biofertilizers on growth and yield attributing attributes in tomato. International J. of Current Microbiology and Applied science, 7 (4); 3686-3694.

Thakur, K.S., Brar, N, S., Kumar, R., Mehta, D.K., Sharma, N., Kumar, D. and Kumar, S. (2015). Effect of organic manures and biofertilizers on fruit yield and its contributing traits of tomato (Solanum lycopersicon L.). Eco.Env.\& Cons, 21 (4): 1783-1787.

\section{How to cite this article:}

Pawde, M. V., A. M. Bhosale and Syed, S. J. 2019. Effect of Liquid Biofertilizers and Inorganic Fertilizers on Yield and Quality Attributes of Broccoli (Brassica oleracea L. var. italica). Int.J.Curr.Microbiol.App.Sci. 8(10): 374-379. doi: https://doi.org/10.20546/ijcmas.2019.810.038 